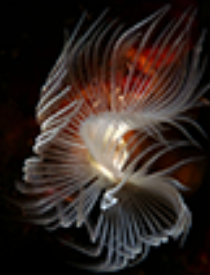

\title{
Phytoplankton diversity of a de-mineralized subtropical reservoir of Meghalaya state, northeast India
}

\section{Bhushan Kumar SHARMA ${ }^{1}$, Sumita SHARMA ${ }^{2}$}

Cite this article as:

Sharma, B.K., Sharma, S. (2021). Phytoplankton diversity of a de-mineralized subtropical reservoir of Meghalaya state, northeast India. Aquatic Research, 4(3), 233-249. https://doi.org/10.3153/AR21018

${ }^{1}$ North-Eastern Hill University, Department of Zoology,

Shillong-793022, Meghalaya, India

${ }^{2}$ Lady Veronica Road, Shillong-793003, Meghalaya, India

ORCID IDs of the author(s): B.K.S. 0000-0002-8019-2684 S.S. 0000-0002-1267-282X

Submitted: 18.10 .2020

Revision requested: 04.12 .2020

Last revision received: 25.12 .2021

Accepted: 13.01.2021

Published online: 19.04.2021

Correspondence:

Bhushan Kumar SHARMA

E-mail: profbksharma@gmail.com

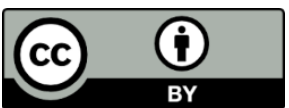

(C) 2021 The Author(s)

\begin{abstract}
This study monitors the spatio-temporal variations of phytoplankton of a soft-water and de-mineralized reservoir of Meghalaya state of northeast India. Phytoplankton assemblages of the littoral and limnetic regions reveal total 36 species and diverse desmids, and contribute dominantly to net plankton abundance. Our results record the quantitative importance of Charophyta $>$ Bacillariophyta $>$ Dinophyta and Charophyta $>$ Dinophyta, and the 'specialist' nature of 11 and six species at the littoral and limnetic regions, respectively. Staurastrum spp. and Cosmarium spp. are notable taxa. Phytoplankton indicates moderate species diversity and depicts dominance and evenness variations. The individual abiotic factors exert differential influence on various taxa at the two regions and the canonical correspondence analysis registers 73.02 and $71.14 \%$ cumulative influence of 10 abiotic factors on the littoral and limnetic assemblages, respectively. The spatial differences of phytoplankton composition, richness, abundance, important groups and taxa, specialist species, diversity indices and the influence of individual abiotic factors are hypothesised to habitat heterogeneity amongst the sampled regions. This study records notable temporal differences of phytoplankton richness, abundance, diversity and the role of abiotic factors vis-a-vis the limited survey of November 1990-October 1991.
\end{abstract}

Keywords: Low conductivity, Primary producers, Spatio-temporal variations, Very soft-water 


\section{Introduction}

Phytoplankton deserves importance as notable contributors to primary production and integral components of aquatic food webs in inland waters. Although these primary producers have been studied from the diverse aquatic environs since the inception of the Indian limnology, a large fraction of works from this country yet represent 'routine' ecology reports because of incomplete species lists and inadequate data-analysis (Sharma and Sharma, 2021). This generalization holds valid for phytoplankton assemblages of lakes and reservoirs of India and north India in particular. The studies from the Himalayan and sub-Himalayan regions of northwest India with variable extents of useful information are from the states of Jammu and Kashmir (Zutshi and Wanganeo, 1984; Wanganeo and Wanganeo, 1991; Baba and Pandit, 2014; Ganai and Parveen, 2014), Himachal Pradesh (Thakur et al., 2013; Jindal et al., 2014a, 2014b; Gupta et al., 2018) and Uttarakhand (Sharma and Singh, 2018; Sharma and Tiwari, 2018). Referring to northeast India (NEI), the noteworthy studies (Sharma, 2004, 2009, 2010, 2012, 2015; Sharma and Hatimuria (2017) are limited to the floodplain lakes (beels and pats) of the states of Assam and Manipur. The detailed studies on phytoplankton diversity of the sub-tropical lacustrine environs of NEI in particular are, however, limited to the works of Sharma and Pachuau (2016), Sharma and Sharma (2021) from the reservoirs of Mizoram and Meghalaya states, respectively.

The present study aims at monitoring the spatio-temporal variations of phytoplankton vis-à-vis abiotic factors of a de-mineralized subtropical reservoir of Meghalaya state of NEI. The littoral and limnetic net plankton are analyzed with reference to species composition, richness, community similarities, abundance, dominant groups, important taxa, notable species, species diversity, dominance and evenness, and the individual and cumulative influence of abiotic factors on phytoplankton assemblages. The results are discussed in comparison with those from the tropical and subtropical lacustrine environs of India, and the floodplain lakes and reservoirs of NEI. Remarks are made on the spatio-temporal variations of phytoplankton diversity based on our results from the littoral and limnetic regions as well as on the temporal variations vs. our earlier preliminary survey (Sharma, 1995) undertaken at the limnetic region.

\section{Material and Methods}

The present study is based on January-December 2014 limnological survey of a small rainwater-fed reservoir (Figure 1, A-C; Latitude $25^{\circ} 34^{\prime} \mathrm{N}$; Longitude $91^{\circ} 56^{\prime} \mathrm{E}$, area $\sim 10$ ha; max. depth: $15 \mathrm{~m}$ ) located at a distance of about $10 \mathrm{~km}$ from Shillong city, the capital of Meghalaya state (refereed as 'Shillong reservoir'). This warm monomictic reservoir (Sharma, 1995) serves as drinking water storage basin and lacks any aquatic vegetation and fish fauna. It is surrounded by forest cover predominated by Plnus kesiya with Cassia sp., Cinnamomum gladulifercum, Rhus javanica and Mochilers khasyana.

Water and the qualitative and quantitative net plankton samples were collected at monthly interval from the littoral and the limnetic regions (Figure 1C). Water temperature was noted using a centigrade thermometer and transparency was noted with a Secchi disc. $\mathrm{pH}$ and specific conductivity were noted with the field probes, dissolved oxygen (DO) was estimated by Winkler's method, and other abiotic factors: free carbon dioxide $\left(\mathrm{CO}_{2}\right)$, alkalinity, hardness, calcium $(\mathrm{Ca})$, magnesium $(\mathrm{Mg})$, chloride $(\mathrm{Cl})$, dissolved organic matter (DOM), phosphate $\left(\mathrm{PO}_{4}\right)$, nitrate $\left(\mathrm{NO}_{3}\right)$ and sulphate $\left(\mathrm{SO}_{4}\right)$ were analyzed following APHA (1992). The rainfall data was collected from the local meteorological station. The qualitative net plankton samples were collected by towing nylobolt plankton net $(\# 40 \mu \mathrm{m})$ and preserved in $5 \%$ formalin. All samples were screened with a Wild Stereoscopic binocular microscope; phytoplankton was observed with Leica stereoscopic microscope (DM 1000) and were identified following Islam and Haroon (1980), Fritter and Manuel (1986), Anand (1998) and John et al. (2002). The community similarities were calculated vide Sørensen index and the hierarchical cluster analysis was done using SPSS (version 20). The monthly quantitative samples were obtained by filtering $25 \mathrm{~L}$ of water each through nylobolt plankton net $(\# 40 \mu \mathrm{m})$ and were preserved in $5 \%$ formalin. The quantitative enumeration of phytoplankton was done by using a Sedgewick-Rafter counting cell and abundance was expressed as ind. $\mathrm{L}^{-1}$. Species diversity, dominance and evenness were computed vides Shannon-Weiner index, Berger-Parker index and $E_{1}$ index, respectively following Ludwig and Reynolds (1988). Twoway analysis of variance (ANOVA) was used to ascertain significance of variations of abiotic and biotic parameters between the sampled regions and months. Pearson correlation 
coefficients for the littoral and limnetic regions $\left(\mathrm{r}_{1}\right.$ and $\mathrm{r}_{2}$, respectively) were calculated between abiotic and biotic parameters; $p$ values (2-tailed) were calculated and their significance was ascertained after applying Bonferroni corrections. The canonical correspondence analysis (XLSTAT 2015) was done to observe cumulative influence of 10 abiotic parameters namely water temperature, rainfall, transparency, specific conductivity, DO, alkalinity, hardness, $\mathrm{Cl}$, DOM and $\mathrm{PO}_{4}$ on phytoplankton assemblages.
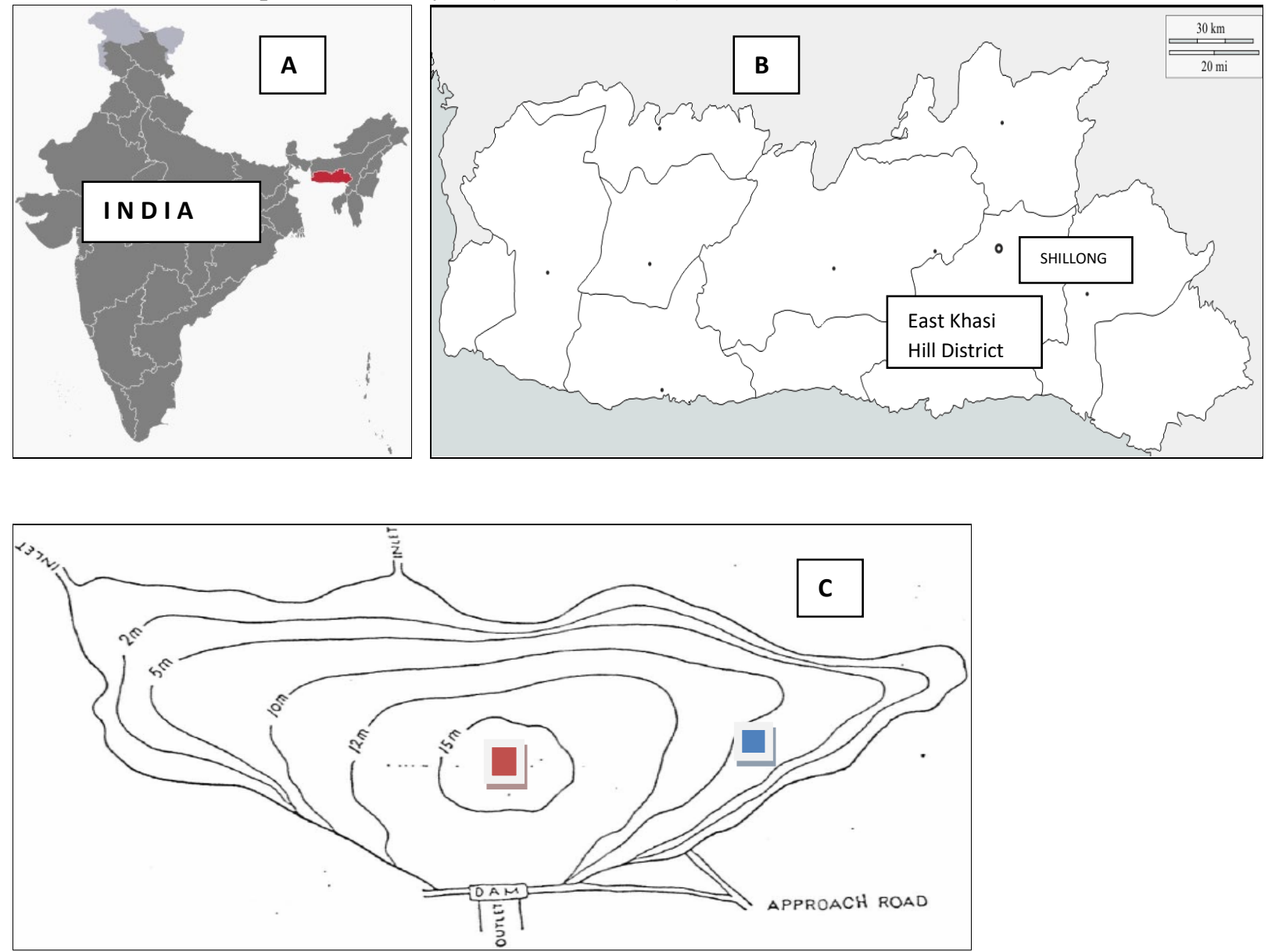

Figure 1(A-C). A, map of India showing Meghalaya state of northeast India (red color); B, map of Meghalaya indicating location of the capital city of Shillong; C, map of Shillong reservoir indicating the littoral (blue color) and limnetic (red color) regions

\section{Results and Discussion}

Our results highlight 'very soft, acidic, highly de-mineralized and distinctly calcium poor' nature of Shillong reservoir with oxygenated waters, low free $\mathrm{CO} 2$ and nutrients, and $\mathrm{Cl}$ indicates the limited human impact (Table 1). We report one of the lowest specific conductivity known till date from aquatic environs of the Indian sub-continent (Hickel, 1973; Sharma and Bhattarai, 2005; Sharma and Sharma, 2021). This notable feature is attributed to predominant effects of abundant rainfall in NEI coupled with the weathered and leached nature of rocks and soils of the catchment area and to the lowered buffering capacity of the de-mineralized waters (Sharma, 1995) of this rain-water fed reservoir. ANOVA registers significant variations of transparency, $\mathrm{DO}, \mathrm{Ca}, \mathrm{Cl}$ and $\mathrm{SO}_{4}$ between the regions and months, while all abiotic factors register significant monthly variations (Table 2). This study records decrease in transparency and $\mathrm{PO}_{4}$, and the relative increase in specific conductivity, alkalinity, hardness and $\mathrm{Cl}$ (Table 1) than the earlier survey (Sharma, 1995).

Total 36 species (Table 3) noted vide our study depict distinctly diverse phytoplankton than the earlier report of 16 species (Sharma, 1995), and the relatively diverse nature than the reports from lacustrine systems of Himachal Pradesh (Jindal and Thakur, 2014; Gupta et al., 2018,) and Uttarakhand (Negi 
and Rajput, 2015), and Meghalaya (Sharma and Lyngskor 2003), and the kingdom of Bhutan (Sharma and Bhattarai 2005). The richness broadly concurs with the reports from Assam (Devi et al., 2016), Himachal Pradesh (Jindal et al., 2014a), Tripura (Bharati et al., 2020), Meghalaya (Sharma and Lyngdoh, 2003) and Uttarakhand (Goswami et al., 2018) but is lower than known from Himachal Pradesh (Jindal et al., 2013, 2014b), Meghalaya (Sharma and Sharma, 2021) and Mizoram (Sharma and Pachuau, 2016). The comparisons highlight fairly species-rich phytoplankton assemblage of 'very soft and highly de-mineralized' waters' of the sampled reservoir in particular. Charophyta, the speciose group, records higher richness than known vide the earlier survey (Sharma, 1995), and the reports from the floodplain lakes of NEI (Sharma, 2009, 2010, 2012, 2015; Devi et al., 2016) and the lakes of Kashmir (Baba and Pandit, 2014) and Uttarakhand (Negi and Rajput, 2015; Goswami et al., 2018; Sharma and Singh, 2018; Sharma and Tiwari, 2018).

Table 1. Variations of abiotic factors

\begin{tabular}{|c|c|c|c|c|c|c|}
\hline & \multicolumn{4}{|c|}{ Present study } & \multicolumn{2}{|c|}{ Nov.1990-Oct.91 } \\
\hline & \multicolumn{2}{|c|}{ Littoral region } & \multicolumn{2}{|c|}{ Limnetic region } & \multirow{2}{*}{$\begin{array}{c}\begin{array}{c}\text { Limnetic re- } \\
\text { gion }\end{array} \\
\text { Range }\end{array}$} & \multirow[b]{2}{*}{ Average \pm S.D } \\
\hline Factors & Range & Average \pm S.D & Range & Average \pm S.D & & \\
\hline Water temperature ${ }^{\circ} \mathrm{C}$ & $11.0-21.0$ & $17.1 \pm 3.5$ & $11.0-20.5$ & $16.8 \pm 3.3$ & $12.0-21.5$ & $17.7 \pm 3.6$ \\
\hline Rainfall $\mathrm{mm}$ & $0.6-780.5$ & $211.6 \pm 223.7$ & $0.6-780.5$ & $211.6 \pm 223.7$ & $1.0-652.0$ & $196 \pm 206$ \\
\hline Transparency m & $1.6-2.2$ & $1.88 \pm 0.16$ & $1.6-2.2$ & $1.93 \pm 0.16$ & $2.0-3.25$ & $2.55 \pm 0.35$ \\
\hline $\mathrm{pH}$ & $5.65-6.67$ & $6.21 \pm 0.22$ & $5.64-6.55$ & $6.16 \pm 0.26$ & $5.5-6.6$ & $6.1 \pm 0.4$ \\
\hline Sp. conductivity $\mu \mathrm{Scm}^{-1}$ & $11.5-19.2$ & $15.8 \pm 2.5$ & $12.0-19.0$ & $15.8 \pm 2.2$ & $6.0-12.0$ & $8.2 \pm 1.8$ \\
\hline DO $\mathrm{mg} \mathrm{L}^{-1}$ & $7.0-8.6$ & $7.8 \pm 0.4$ & $7.2-8.8$ & $7.9 \pm 0.4$ & $6.7-10.2$ & $8.3 \pm 0.8$ \\
\hline Free $\mathrm{CO}_{2} \mathrm{mg} \mathrm{L}^{-1}$ & $4.8-9.2$ & $7.2 \pm 1.5$ & $4.0-9.0$ & $6.7 \pm 1.4$ & $4.0-9.3$ & $6.5 \pm 1.3$ \\
\hline Alkalinity mg L $\mathrm{m}^{-1}$ & $9.0-16.8$ & $11.8 \pm 2.3$ & $9.2-16.4$ & $11.7 \pm 2.1$ & $5.6-11.8$ & $8.5 \pm 1.8$ \\
\hline Hardness $\mathrm{mg} \mathrm{L}^{-1}$ & $6.2-13.2$ & $8.6 \pm 2.2$ & $6.0-13.0$ & $8.7 \pm 2.2$ & $4.0-12.2$ & $7.5 \pm 4.3$ \\
\hline $\mathrm{Ca} \mathrm{mg} \mathrm{L}^{-1}$ & $3.8-7.6$ & $5.3 \pm 1.2$ & $3.6-7.0$ & $5.0 \pm 1.3$ & $1.6-9.5$ & $4.7 \pm 2.5$ \\
\hline $\mathrm{Mg} \mathrm{mg} \mathrm{L}^{-1}$ & $0.2-0.9$ & $0.2 \pm 0.3$ & $0.2-0.8$ & $0.4 \pm 0.2$ & $0.2-1.1$ & $0.6 \pm 0.5$ \\
\hline $\mathrm{Cl} \mathrm{mg} \mathrm{L}^{-1}$ & $19.0-42.0$ & $30.4 \pm 6.7$ & $18.0-40.0$ & $29.4 \pm 6.4$ & $4.0-8.8$ & $5.5 \pm 1.2$ \\
\hline $\mathrm{PO}_{4} \mathrm{mg} \mathrm{L}^{-1}$ & $0.072-0.190$ & $0.128 \pm 0.035$ & $0.080-0.190$ & $0.128 \pm 0.031$ & $0.100-0.280$ & $0.150 \pm 0.050$ \\
\hline $\mathrm{SO}_{4} \mathrm{mg} \mathrm{L}^{-1}$ & $1.642-2.905$ & $2.253 \pm 0.447$ & $1.640-2.810$ & $2.202 \pm 0.423$ & $1.000-3.500$ & $2.200 \pm 0.700$ \\
\hline $\mathrm{NO}_{3} \mathrm{mg} \mathrm{L}^{-1}$ & $0.066-0.196$ & $0.108 \pm 0.040$ & $0.070-0.188$ & $0.110 \pm 0.036$ & $0.010-0.040$ & $0.023 \pm 0.010$ \\
\hline $\mathrm{DOM} \mathrm{mg} \mathrm{L}^{-1}$ & 0.4-3.0 & $1.3 \pm 0.9$ & $0.5-3.0$ & $1.5 \pm 0.9$ & - & \\
\hline
\end{tabular}

Table 2. ANOVA indicating significance of abiotic factors

\begin{tabular}{|l|c|c|}
\hline Parameters & Regions & Months \\
\hline Water temperature & - & $\mathrm{F}_{11,23}=244.629, \mathrm{P}<0.0001$ \\
\hline Transparency & $\mathrm{F}_{1,23}=17.742, \mathrm{P}=0.001$ & $\mathrm{~F}_{11,23}=9.069, \mathrm{P}=0.0003$ \\
\hline $\mathrm{pH}$ & - & $\mathrm{F}_{11,23}=196.986, \mathrm{P}<0.0001$ \\
\hline Specific conductivity & - & $\mathrm{F}_{11,23}=66.715, \mathrm{P}<0.0001$ \\
\hline $\mathrm{DO}$ & $\mathrm{F}_{1,23}=10.632, \mathrm{P}=0.007$ & $\mathrm{~F}_{11,23}=30.779, \mathrm{P}<0.0001$ \\
\hline Free $\mathrm{CO}_{2}$ & - & $\mathrm{F}_{11,23}=6.372, \mathrm{P}=0.0024$ \\
\hline Alkalinity & - & $\mathrm{F}_{11,23}=129.223, \mathrm{P}<0.0001$ \\
\hline Hardness & - & $\mathrm{F}_{11,23}=342.936, \mathrm{P}<0.0001$ \\
\hline $\mathrm{Ca}$ & $\mathrm{F}_{1,23}=27.770, \mathrm{P}=0.0002$ & $\mathrm{~F}_{11,23}=78.814, \mathrm{P}<0.0001$ \\
\hline $\mathrm{Mg}$ & - & $\mathrm{F}_{11,23}=17.551, \mathrm{P}<0.0001$ \\
\hline $\mathrm{Cl}$ & $\mathrm{F}_{1,23}=15.531, \mathrm{P}=0.002$ & $\mathrm{~F}_{11,23}=220.202, \mathrm{P}<0.0001$ \\
\hline $\mathrm{PO}$ & - & $\mathrm{F}_{11,23}=157.459, \mathrm{P}<0.0001$ \\
\hline $\mathrm{SO}_{4}$ & $\mathrm{~F}_{1,23}=8.302, \mathrm{P}=0.015$ & $\mathrm{~F}_{11,23}=219.202, \mathrm{P}<0.0001$ \\
\hline $\mathrm{NO}_{3}$ & - & $\mathrm{F}_{11,23}=195.429, \mathrm{P}<0.0001$ \\
\hline $\mathrm{DOM}^{-}$ & - & $\mathrm{F}_{11,23}=189.7048, \mathrm{P}<0.0001$ \\
\hline
\end{tabular}

(-) insignificant variations 
The soft, calcium-poor and de-mineralized waters are known for high desmid richness (Woelkerling and Gough, 1976; Payne, 1986). This generalization is affirmed by the rich desmid diversity noted vide our study which include five species each of Staurastrum and Cosmarium, and one species each of Arthrodesmus, Closterium, Euastrum, Micrasterias, Netrium and Sirogonium. Our results concur with the richness importance of Staurastrum $=$ Cosmarium observed from a reservoir of Meghalaya (Sharma and Sharma, 2021). This trend, however, differs from the importance of Staurastrum (Sharma, 1995), and high richness of Closterium > Cosmarium $>$ Staurastrum $>$ Micrasterias $>$ Gonatozygon (Sharma, 2009), Closterium $>$ Cosmarium $>$ Micrasterias $>$ Gonatozygon (Sharma, 2010), Staurastrum $>$ Cosmarium $>$ Micrasterias (Sharma and Pachuau, 2016), and Cosmarium > Staurastrum $>$ Euastrum (Sharma and Hatimuria, 2017) known from various aquatic environs of NEI.

Our study records higher phytoplankton monthly richness at the littoral than the limnetic region (Table 3). The differential variation, hypothesized to greater habitat heterogeneity of the former region, is affirmed by significant richness variations (Table 4) between the regions (vide ANOVA). Phytoplankton contribute to net plankton richness at the two regions $\left(\mathrm{r}_{1}=\right.$ $0.746, p=0.013 ; r_{2}=0.735, p=0.015$ ). Peak richness is recorded during winter (January) and maxima during autumn- winter (November-December) at the littoral region, and the limnetic region indicates peak in May (Figure 2). The winter peak at the former region concurs with the reports Manipur (Sharma, 2010), Meghalaya (Sharma and Sharma, 2021) and Assam (Devi et al., 2016), while the peak richness at the limnetic region corresponds with the summer peaks vides Sharma $(2004,2012,2015)$. A notable constellation of 30 phytoplankton species during January collection from the littoral region depicts the possibility of co-existence of a number of species in this small and relatively shallow reservoir due to high amount of niche overlap as hypothesized by MacArthur (1965). Charophyta (Table 3) contribute to phytoplankton richness $\left(\mathrm{r}_{1}=0.688, \mathrm{p}=0.028 ; \mathrm{r}_{2}=0.910, \mathrm{p}=0.0003\right)$ at the two regions. Phytoplankton register $66.7-92.0 \%$ and $54.0-91.7 \%$ community similarities at the littoral and limnetic regions (Table 3), respectively and thus indicate the relatively more heterogeneity at the latter region. This generalization is endorsed by the similarity values ranging between $71-90 \%$ in $\sim 89 \%$ instances at the littoral region as against $\sim 77 \%$ instances with similarities ranging between $61-80 \%$ at the limnetic region. The hierarchical cluster groupings (Figures 3-4) record peak affinity between February-November and AprilMay collections, while July $>$ September $>$ June communities record maximum species divergence at the littoral region. The limnetic phytoplankton, however, indicate peak affinity between April-May and maximum divergence during July.

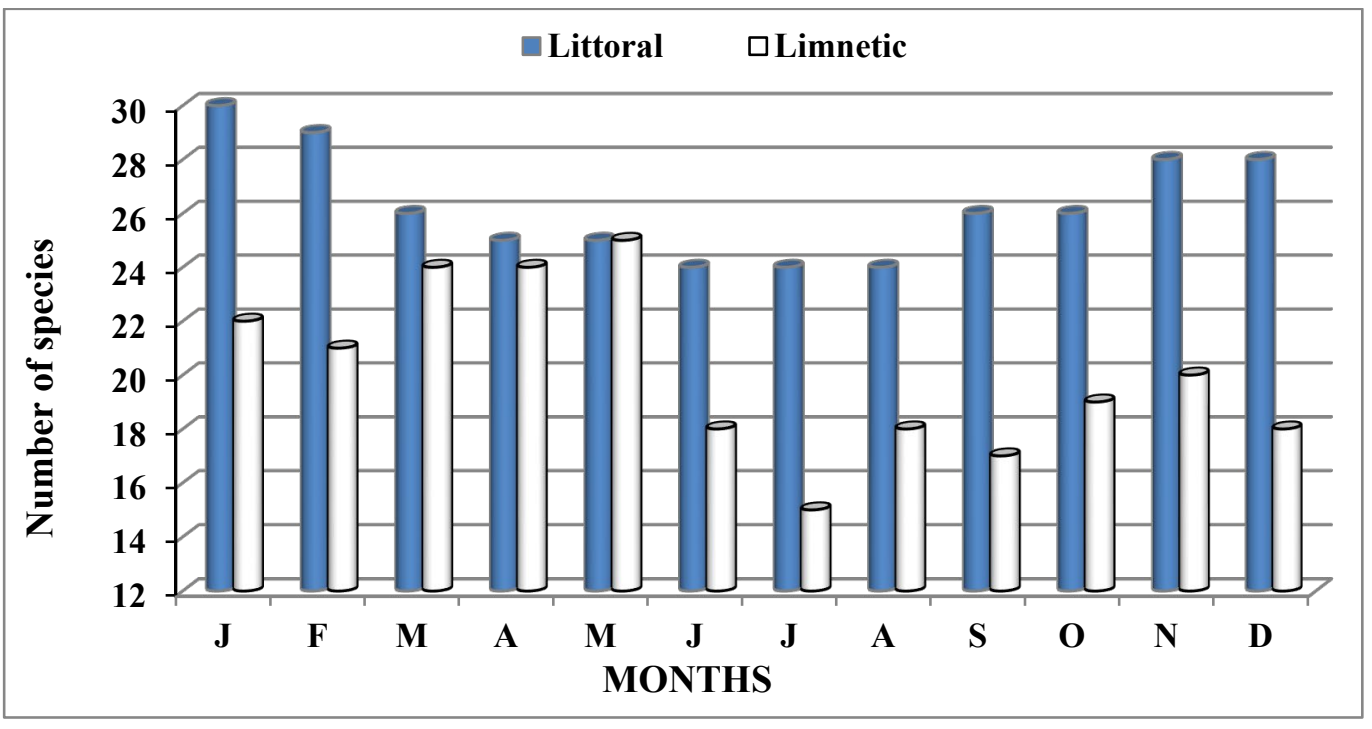

Figure 2. Monthly variations of phytoplankton richness 


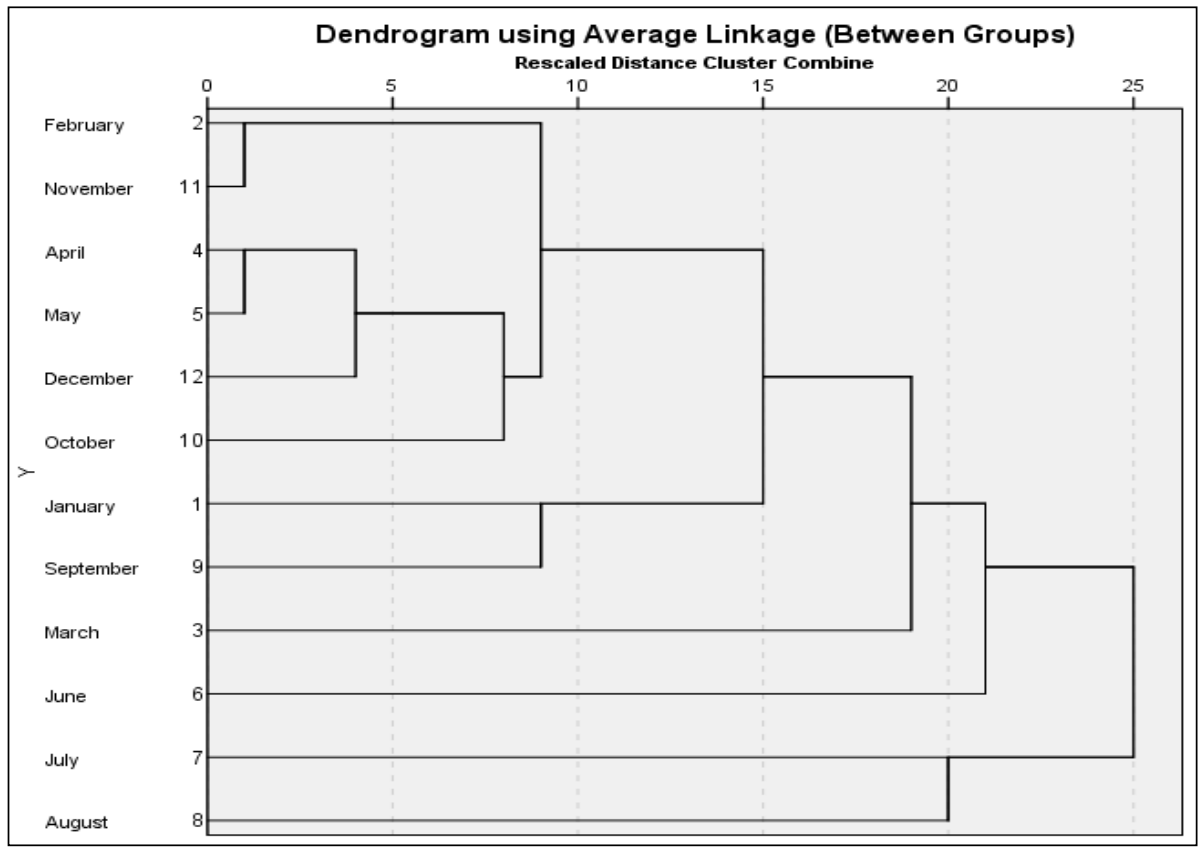

Figure 3. Hierarchical cluster analysis of phytoplankton assemblages (Littoral region)

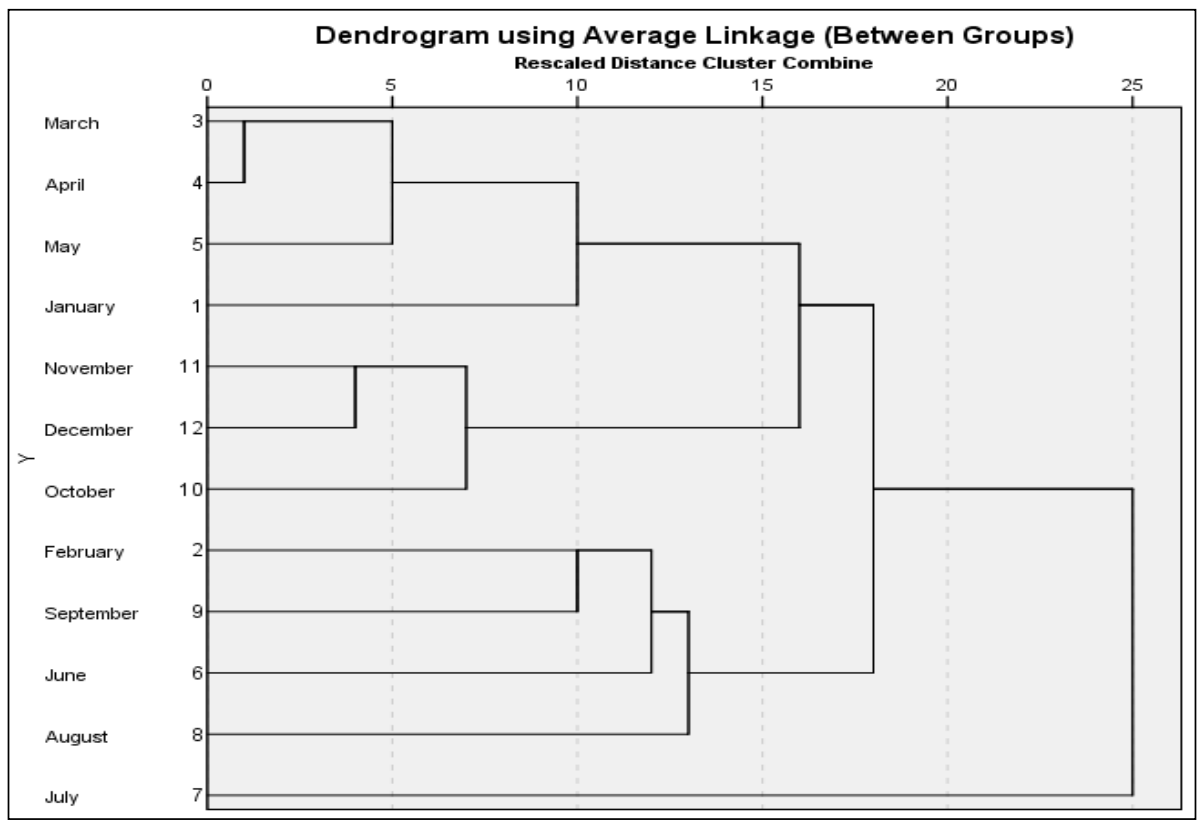

Figure 4. Hierarchical cluster analysis of phytoplankton assemblages (Limnetic region) 
Table 3. Richness, abundance and diversity indices of phytoplankton assemblages

\begin{tabular}{|c|c|c|c|c|c|}
\hline & \multicolumn{4}{|c|}{ Present study } & \multirow{2}{*}{\begin{tabular}{|c|} 
Nov.1990-Oct.91 \\
Limnetic region
\end{tabular}} \\
\hline Qualitative & \multicolumn{2}{|c|}{ Littoral region } & \multicolumn{2}{|c|}{ Limnetic region } & \\
\hline Net Plankton & \multicolumn{2}{|c|}{72 species } & \multicolumn{2}{|c|}{67 species } & 28 species \\
\hline Phytoplankton & \multicolumn{2}{|l|}{36 species } & \multicolumn{2}{|l|}{30 species } & 16 species \\
\hline Monthly richness & $24-30$ & $26 \pm 2$ & \multirow{2}{*}{\multicolumn{2}{|c|}{$\begin{array}{l}15-25 \\
54.0-91.7\end{array}$}} & \multirow{2}{*}{$\begin{array}{ll}3-14 & 8 \pm 3 \\
- & \end{array}$} \\
\hline Community similarity $\%$ & \multicolumn{2}{|l|}{$66.7-92.0$} & & & \\
\hline Charophyta & \multirow{2}{*}{\multicolumn{2}{|c|}{$\begin{array}{l}19 \text { species } \\
11-15\end{array}$}} & \multicolumn{2}{|l|}{16 species } & \multirow{2}{*}{9 species } \\
\hline Monthly richness & & & $7-13$ & $11 \pm 2$ & \\
\hline \multicolumn{6}{|l|}{ Quantitative } \\
\hline Net plankton (ind. $\mathrm{L}^{-1}$ ) & 189-1089 & $551 \pm 239$ & $158-430$ & $285 \pm 87$ & $13-400 \quad 109 \pm 104$ \\
\hline Phytoplankton (ind. L ${ }^{-1}$ ) & $95-887$ & $429 \pm 230$ & $74-364$ & $216 \pm 93$ & $7-318 \quad 98 \pm 100$ \\
\hline Percentage & $44.8-90.0$ & $73.7 \pm 14.4$ & $46.8-86.9$ & $73.0 \pm 12.4$ & $53.9-95.8$ \\
\hline Species Diversity & $2.061-2.767$ & $2.443 \pm 0.238$ & $1.885-2.654$ & $2.279 \pm 0.236$ & $0.959-1.787 \quad 1.330 \pm 0.477$ \\
\hline Dominance & $0.156-0.408$ & $0.285 \pm 0.099$ & $0.187-0.464$ & $0.278 \pm 0.093$ & $\begin{array}{ll}0.265-0.883 & 0.542 \pm 0.212\end{array}$ \\
\hline Evenness & $0.618-0.871$ & $0.745 \pm 0.088$ & $0.658-0.859$ & $0.765 \pm 0.056$ & $0.177-0.917 \quad 0.537 \pm 0.477$ \\
\hline Charophyta (ind. $\mathrm{L}^{-1}$ ) & $30-636$ & $174 \pm 191$ & $49-219$ & $100 \pm 50$ & $2-275 \quad 51 \pm 79$ \\
\hline Percentage & $11.8-71.7$ & $37.4 \pm 16.6$ & $46.8-86.9$ & $47.1 \pm 11.4$ & $2.4-85.1$ \\
\hline Bacillariophyta (ind. L-1) & $29-312$ & $140 \pm 50$ & $8-66$ & $34 \pm 20$ & $1-8$ \\
\hline Percentage & $11.7-58.1$ & $35.6 \pm 14.8$ & $6.4-23.6$ & $15.0 \pm 5.3$ & - \\
\hline Dinophyta (ind. $\mathrm{L}^{-1}$ ) & $11-299$ & $105 \pm 90$ & $12-130$ & $72 \pm 34$ & $42 \pm 39$ \\
\hline Percentage & $10.1-39.7$ & $24.7 \pm 11.6$ & $13.3-52.3$ & $32.8 \pm 12.8$ & $8.5-96.0$ \\
\hline Chrysophyta (ind. L ${ }^{-1}$ ) & $0-38$ & $8 \pm 2$ & $0-47$ & $9 \pm 13$ & $1 \pm 2$ \\
\hline Cryptophyta (ind. L L $^{-1}$ ) & $0-3$ & $2 \pm 0$ & $0-3$ & $2 \pm 1$ & - \\
\hline Cyanobacteria (ind. $\mathrm{L}^{-1}$ ) & $0-2$ & $1 \pm 0$ & $0-2$ & $2 \pm 0$ & $2 \pm 2$ \\
\hline Euglenophyta (ind. L $\left.\mathrm{L}^{-1}\right)$ & $0-3$ & $2 \pm 0$ & $0-3$ & $1 \pm 0$ & - \\
\hline \multicolumn{6}{|c|}{ Important taxa (ind. $\mathrm{L}^{-1}$ ) } \\
\hline Staurastrum spp. & $14-570$ & $135 \pm 150$ & $31-204$ & $73 \pm 45$ & $20 \pm 28$ \\
\hline Cosmarium spp. & $4-38$ & $19 \pm 12$ & $2-54$ & $15 \pm 17$ & - \\
\hline \multicolumn{6}{|c|}{ Important species (ind. $\mathrm{L}^{-1}$ ) } \\
\hline Peridinium cinctum & $6-270$ & $66 \pm 80$ & $13-95$ & $42 \pm 27$ & $13 \pm 15$ \\
\hline Staurastrum freemani & $2-301$ & $63 \pm 83$ & $5-130$ & $31 \pm 32$ & $20 \pm 28$ \\
\hline Staurastrum arctiscon & $2-201$ & $49 \pm 53$ & $5-32$ & $16 \pm 8$ & $12 \pm 23$ \\
\hline Navicula radiosa & $6-242$ & $61 \pm 68$ & $2-51$ & $21 \pm 15$ & - \\
\hline Ceratium hirudinella & $5-91$ & $38 \pm 25$ & $2-100$ & $30 \pm 26$ & $29 \pm 38$ \\
\hline Tabellaria flocculosa & $5-60$ & $24 \pm 18$ & $2-18$ & $9 \pm 5$ & - \\
\hline Staurastrum gutwinckii & $2-41$ & $17 \pm 11$ & $8-43$ & $24 \pm 11$ & $16 \pm 30$ \\
\hline Cosmarium decoratum & $0-21$ & $10 \pm 7$ & $0-11$ & $4 \pm 4$ & - \\
\hline Pinnularia viridis & $0-46$ & $12 \pm 16$ & $0-1$ & $1 \pm 1$ & - \\
\hline Frustulia rhomboides & $2-27$ & $11 \pm 7$ & $0-7$ & $2 \pm 2$ & - \\
\hline Caloneis bacillum & $0-40$ & $10 \pm 12$ & $0-1$ & $1 \pm 1$ & - \\
\hline
\end{tabular}


Table 4. ANOVA indicating significance of phytoplankton assemblages

\begin{tabular}{|l|l|l|}
\hline Parameters & Regions & Months \\
\hline Phytoplankton richness & $\mathrm{F}_{1,23}=40.590, \mathrm{P}<0.0001$ & - \\
\hline Charophyta richness & $\mathrm{F}_{1,23}=24.267, \mathrm{P}=0.0004$ & - \\
\hline Phytoplankton abundance & $\mathrm{F}_{1,23}=19.260, \mathrm{P}=0.001$ & $\mathrm{~F}_{11,23}=3.811, \mathrm{P}=0.018$ \\
\hline Charophyta abundance & - & - \\
\hline Bacillariophyta abundance & $\mathrm{F}_{1,23}=30.107, \mathrm{P}=0.0003$ & - \\
\hline Dinophyta abundance & - & $\mathrm{F}_{11,23}=5.731, \mathrm{P}=0.0367$ \\
\hline Chrysophyta abundance & - & $\mathrm{F}_{11,23}=5.099, \mathrm{P}<0.0001$ \\
\hline Species diversity & $\mathrm{F}_{1,23}=4.163, \mathrm{P}=0.066$ & $\mathrm{~F}_{11,23}=9.024, \mathrm{P}=0.0005$ \\
\hline Abundance of Important taxa and species & \\
\hline Staurastrum spp. & - & $\mathrm{F}_{11,23}=2.934, \mathrm{P}=0.043$ \\
\hline Cosmarium spp. & - & - \\
\hline Ceratium hirudinella & - & $\mathrm{F}_{11,23}=11.092, \mathrm{P}=0.0002$ \\
\hline Cosmarium decoratum & $\mathrm{F}_{1,23}=10.329, \mathrm{P}=0.008$ & - \\
\hline Navicula radiosa & $\mathrm{F}_{1,23}=5.638, \mathrm{P}=0.036$ & - \\
\hline Peridinium cinctum & - & $\mathrm{F}_{11,23}=3.019, \mathrm{P}=0.040$ \\
\hline Staurastrum freemani & - & $\mathrm{F}_{11,23}=4.422, \mathrm{P}=0.010$ \\
\hline Staurastrum arctiscon & $\mathrm{F}_{1,23}=5.085, \mathrm{P}=0.045$ & - \\
\hline Staurastrum gutwinckii & $\mathrm{F}_{1,23}=7.727, \mathrm{P}=0.018$ & $\mathrm{~F}_{11,23}=6.563, \mathrm{P}=0.002$ \\
\hline Tabellaria flocculosa & $\mathrm{F}_{1,23}=10.277, \mathrm{P}=0.008$ & - \\
\hline Caloneis bacillum & $\mathrm{F}_{1,23}=7.176, \mathrm{P}=0.021$ & - \\
\hline Frustulia rhomboides & $\mathrm{F}_{1,23}=20.502, \mathrm{P}=0.001$ & - \\
\hline Pinnularia viridis & $\mathrm{F}_{1,23}=6.538, \mathrm{P}=0.027$ & - \\
\hline
\end{tabular}

(-) insignificant variations

Phytoplankton comprise dominant quantitative component and significantly influence net plankton abundance $\left(\mathrm{r}_{1}=\right.$ $\left.0.978, \mathrm{p}<0.0001 ; \mathrm{r}_{2}=0.982, \mathrm{p}<0.0001\right)$ at the littoral and limnetic regions (Table 3), and register significant density variations (Table 4) between the two regions (vide ANOVA). Phytoplankton dominance concurs with the reports from Assam (Sharma and Hatimuria, 2017), Himachal Pradesh (Jindal and Thakur, 2014), Meghalaya (Sharma, 1995; Sharma and Lyngdoh, 2003) and Mizoram (Sharma and Pachuau, 2016). The wider density variations and higher abundance (Table 3) at the littoral than the limnetic region are hypothesized to greater habitat heterogeneity of the former region. Our results depict three- and two-fold higher abundance at the two regions, respectively than the earlier survey (Sharma, 1995). This study records bimodal monthly phytoplankton density variations at the two regions (Figures 5-6) concurrent with the reports of Baba and Pandit (2014), Goswami et al. (2018) and (Sharma and Sharma, 2021). The peak abundance noted during October and winter maxima at the two regions deviate from the mid-monsoon peak (Sharma and Bhattarai, 2005) and from the autumn peaks reported from Kashmir (Baba and Pandit, 2014), Meghalaya (Sharma and Sharma, 2020), Mizoram (Sharma and Pachuau, 2016) and Uttarakhand (Sharma and Singh, 2018). The winter maxima concur with the results of Wanganeo and Wanganeo (1991), Sharma (1995, 2004, 2009, 2010), Sharma and Lyngdoh (2003), Sharma and Hatimuria (2017), Goswami et al. (2018), Sharma and Tiwari (2018) and Sharma and Sharma (2021). Phytoplankton indicate the differential spatial quantitative importance of Charophyta $>$ Bacillariophyta $>$ Dinophyta and Charophyta $>$ Dinophyta at the littoral and limnetic, respectively (Table 3). Charophyta result in late-monsoon phytoplankton peak, Bacillariophyta $>$ Charophyta contribute to winter maxima and Charophyta $>$ Dinophyta result in high abundance during November-December at the littoral region (Figure 5). Charophyta $>$ Dinophyta influence latemonsoon peak and Charophyta influence winter maxima at the limnetic region (Figure 6). 


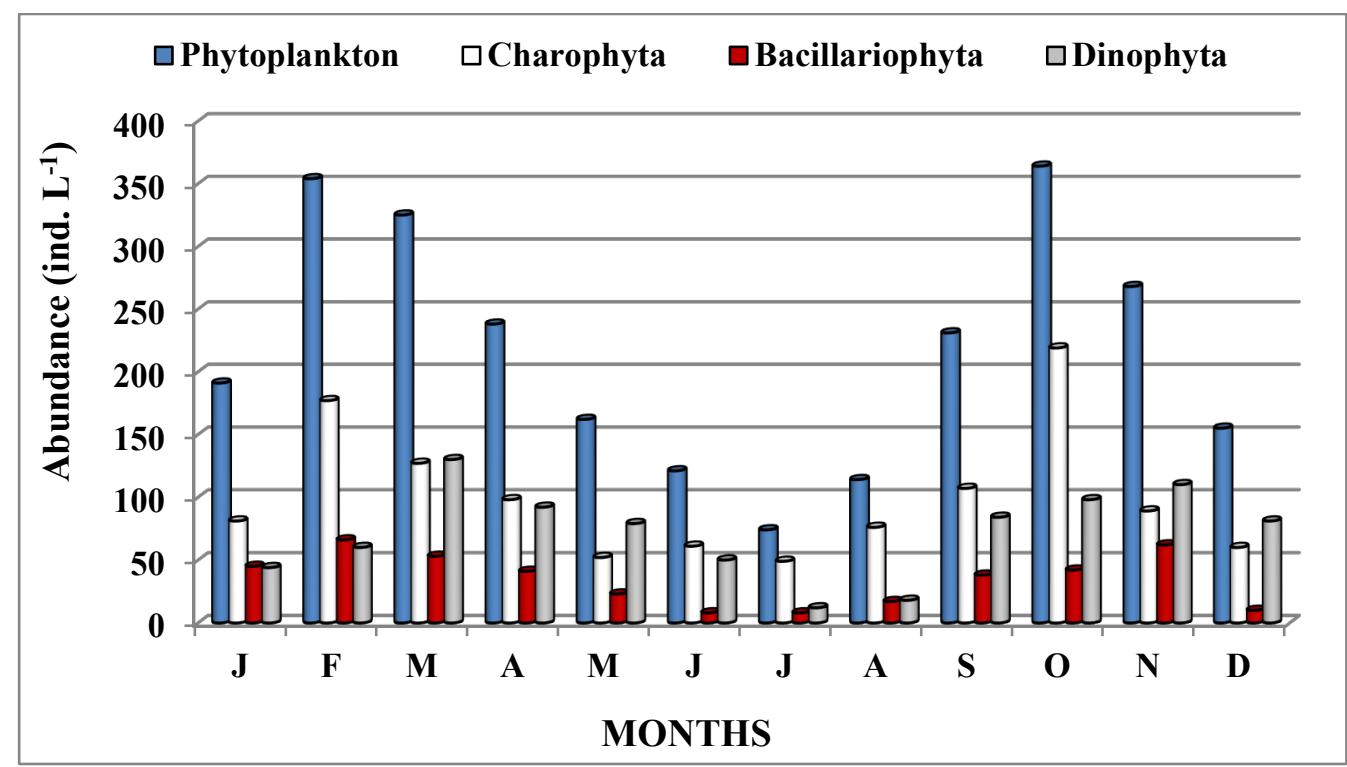

Figure 5. Monthly variations of abundance of phytoplankton and important groups (Littoral region)

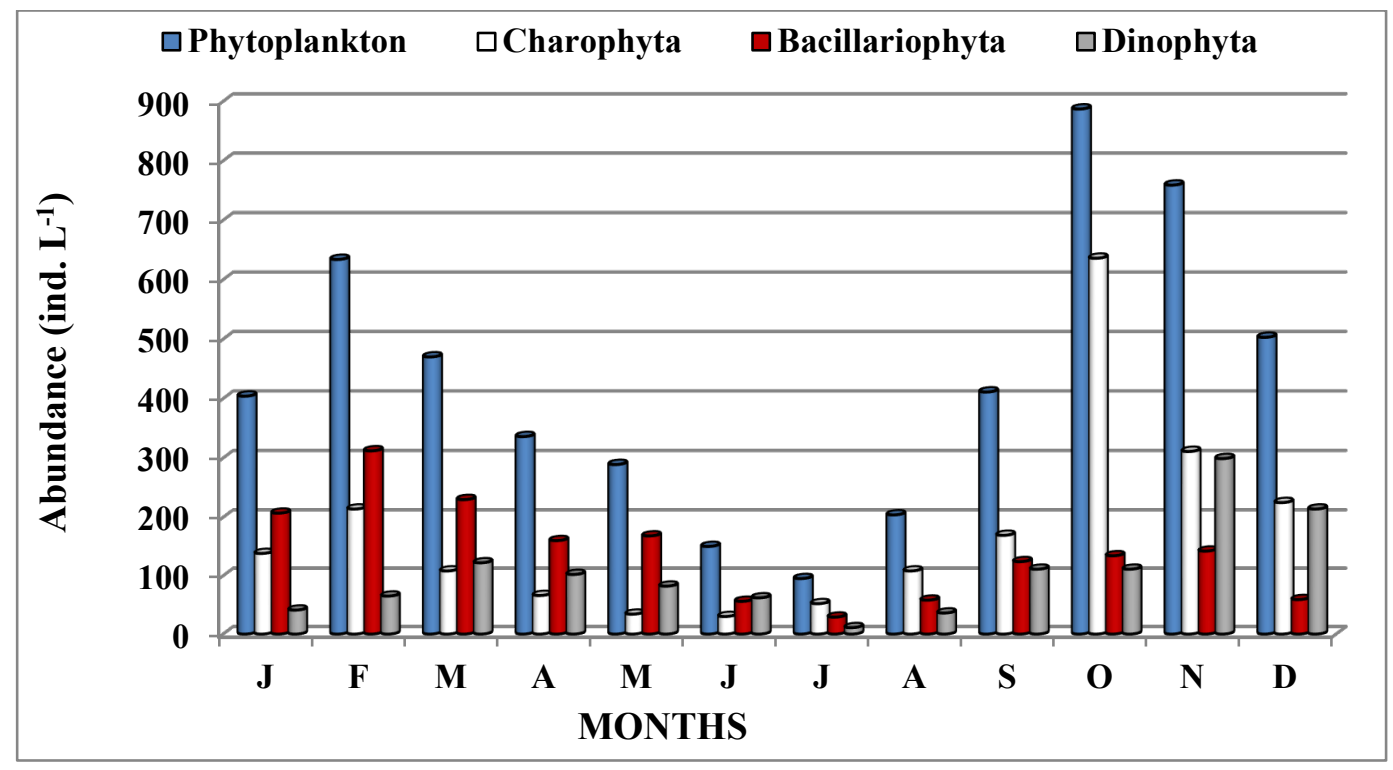

Figure 6. Monthly variations of abundance of phytoplankton and important groups (Limnetic region)

Peridinium cinctum $>$ Staurastrum freemani $>$ S. arctiscon $>$ Navicula radiosa $>$ Ceratium hirudinella $>$ Tabellaria flocculosa $>$ S. gutwinckii $>$ Cosmarium contractum $>$ Pinnularia viridis $>$ Frustulia rhomboides $>$ Caloneis bacillum indicate the stated order of the quantitative importance at the littoral region (Table 3). Peridinium cinctum $>$ Staurastrum freemani $>$ Ceratium hirudinella $>$ S. gutwinckii $>$ Navicula radiosa $>$ S. arctiscon are notable at the limnetic region (Table 3). Our results categorize the 'specialists' nature of 11 and six species at the two regions, respectively and the 'generalist' nature of the rest of species with lower densities. Following MacArthur (1965) explanation, it is hypothesized that Shillong reservoir has resources for utilization both by the 'specialist' and 'generalist' species. The 'specialist' species collectively $(84.0 \pm 8.1,79.8 \pm 9.3 \%)$ influence phytoplankton abundance $\left(\mathrm{r}_{1}=0.994, \mathrm{p}<0.0001 ; \mathrm{r}_{2}=0.941, \mathrm{p}<0.0001\right)$ at the two regions, respectively. Of these, Staurastrum arctiscon $\left(\mathrm{r}_{1}=\right.$ $0.875, \mathrm{p}=0.0009), S$. freemanni $\left(\mathrm{r}_{1}=0.829, \mathrm{p}=0.003\right)$ and Cosmarium decoratum $\left(\mathrm{r}_{1}=0.846, \mathrm{p}=0.002\right)$ individually influence phytoplankton abundance at the littoral region, while 
Navicula radiosa $\left(\mathrm{r}_{2}=0.840, \mathrm{p}=0.001\right)$, Staurastrum arctiscon $\left(\mathrm{r}_{2}=0.955, \mathrm{p}<0.0001\right)$ and Tabellaria flocculosa $\left(\mathrm{r}_{2}=\right.$ $0.716, \mathrm{p}=0.020$ ) exert influence at the limnetic region. Staurastrum freemani $>S$. arctiscon are main contributors to latemonsoon phytoplankton peak at the littoral region while the dominant $N$. radiosa contributes to winter maxima. The differential spatial importance of the 'specialist' species noted vide the present study concurs with the report of Sharma and Sharma (2021).

Charophyta (Table 3 ) contributes to the littoral and limnetic phytoplankton abundance $\left(\mathrm{r}_{1}=0.763, \mathrm{p}=0.010 ; \mathrm{r}_{2}=0.892, \mathrm{p}\right.$ $=0.0005)$ and follows the bimodal monthly variations (Figures 5-6) identical with that of phytoplankton. The bimodal periodicity of the green algae differs from unimodal patterns reported by Baba and Pandit (2014) and Ganai and Parveen (2014). Charophyta indicates three- and two-fold higher abundance at the two regions (Table 3), respectively higher than the earlier survey (Sharma, 1995) and also records higher abundance than known from the reservoirs of Meghalaya (Sharma and Lyngskor, 2003; Sharma and Lyngdoh 2003) and Mizoram (Sharma and Pachuau, 2016) and the floodplain lakes (Sharma, 2004, 2009, 2010, 2012, 2015; Sharma and Hatimuria, 2017) of NEI. Staurastrum freemani $>S$. arctiscon influence late-monsoon Charophyta peak, while Staurastrum arctiscon $>$ S. freemani contribute to the winter maxima at the littoral region. Staurastrum freemani $>$ S. gutwinckii $>$ S. arctiscon and S. freemani $=S$. gutwinckii $>$ $S$. arctiscon $>$ Cosmarium contractum result in late-monsoon peak and winter maxima, respectively at the limnetic region. ANOVA records (Table 4) significant variations of $C$. contractum and $S$. arctiscon abundance between the regions, $S$. freemani records significant density variations between the regions and months, and $S$. gutwinckii records significant monthly quantitative variations.

Staurastrum spp. (Table 3) contribute to Charophyta $\left(\mathrm{r}_{1}=\right.$ $\left.0.715, \mathrm{p}=0.020 ; \mathrm{r}_{2}=0.918, \mathrm{p}=0.0002\right)$ and phytoplankton $\left(r_{1}=0.837, p=0.002 ; r_{2}=0.722, p=0.018\right)$ abundance and influence their pre-monsoon peaks and winter maxima at the two regions, respectively. Cosmarium spp. contribute to Charophyta $\left(\mathrm{r}_{1}=0.737, \mathrm{p}=0.015\right)$ and phytoplankton $\left(\mathrm{r}_{1}=\right.$ $0.890, \mathrm{p}=0.001$ ) abundance at the littoral region (Table 3 ). The importance of Staurastrum spp. > Cosmarium spp. concurs with the report of Sharma and Sharma (2021) but it differs from the quantitative significance of Staurastrum spp. (Sharma, 1995), Staurastrum spp. > Xanthidium spp. > Cosmarium spp. (Sharma and Pachuau, 2016), Closterium spp. $>$
Staurastrum spp. > Gonatozygon spp. > Micrasterias spp. > Cosmarium spp. (Sharma, 2009); Closterium spp.> Gonatozygon spp.> Micrasterias spp. > Staurastrum spp. from Utra Pat (Sharma, 2010), and Closterium spp. > Cosmarium spp. $>$ Staurastrum spp. > Xanthidium spp. from Waithou Pat (Sharma, 2010) known vide the different reports from NEI. Staurastrum arctiscon $\left(\mathrm{r}_{1}=0.979, \mathrm{p}<0.0001\right)$ and $S$. freemani $\left(\mathrm{r}_{1}=0.996, \mathrm{p}<0.0001\right)$, and $S$. arctiscon $\left(\mathrm{r}_{2}=0.735, \mathrm{p}=\right.$ $0.015)$, S. freemani $\left(\mathrm{r}_{2}=0.968, \mathrm{p}<0.0001\right)$ and $S$. gutwinckii $\left(\mathrm{r}_{2}=0.725, \mathrm{p}=0.018\right)$ influence Staurastrum spp. abundance at the two regions, respectively. Cosmarium decoratum $\left(\mathrm{r}_{1}=\right.$ $0.846, \mathrm{p}=0.002$ ) influences Cosmarium spp. abundance at the littoral region.

Bacillariophyta (Table 3) comprises an important quantitative component of phytoplankton at the littoral region but records sub-dominance at the limnetic region. The differential spatial importance is affirmed by significant density variations (Table 4) of the diatoms between the two regions (vide ANOVA). Our results mark a distinct contrast to very poor diatom abundance reported vide the earlier limnetic survey (Sharma, 1995). Bacillariophyta importance at the littoral region concurs with the reports from Assam (Sharma, 2015; Sharma \& Hatimuria, 2017), Himachal Pradesh (Jindal et al., 2014b), Kashmir (Baba and Pandit, 2014) and Uttarakhand (Goswami et al., 2018). The diatom sub-dominance at the limnetic region, however, corresponds with the reports from Manipur (Sharma, 2009) and Uttarakhand (Sharma and Singh, 2018). The diatoms record peak abundance during winter (February) and maxima during autumn (November) at the two regions (Figures 5-6). The winter peaks concur with the reports from Kashmir (Wanganeo and Wanganeo, 1991; Baba and Pandit, 2014), Meghalaya (Sharma and Lyngdoh, 2003) and Manipur (Sharma, 2009) and autumn maxima agree with the report from Meghalaya (Sharma and Sharma, 2021). Navicula radiosa contributes to Bacillariophyta $\left(\mathrm{r}_{1}=\right.$ $\left.0.699, \mathrm{p}=0.024 ; \mathrm{r}_{2}=0.980, \mathrm{p}<0.0001\right)$ abundance and influences winter peaks and $N$. radiosa $>$ Tabellaria flocculosa influence autumn maxima at the two regions. ANOVA (Table 4) registers significant density variations of $N$. radiosa, $T$. flocculosa, Caloneis bacillum, Frustulia rhomboides and Pinnularia viridis between the two regions.

Dinophyta (Table 3) contributes significantly to phytoplankton abundance at the limnetic region $\left(\mathrm{r}_{2}=0.709, \mathrm{p}=0.022\right)$ and registers (Table 4) significant monthly density variations (vide ANOVA). Our results record distinctly higher Dinophyta abundance than the earlier survey (Sharma, 1995), 
while it differs from poor abundance reported by Sharma and Lyngdoh (2003), Sharma and Lyngskor (2003), Sharma (2010), Sharma and Pachuau (2016) and Sharma and Hatimuria (2017) from NEI. Dinophyta abundance depicts the differential spatial patterns (Figures 5-6) with peak in autumn (November) and maxima in spring (March) at the littoral region, and it records peak in spring and maxima in autumn at the limnetic region. Peaks and maxima differ from winter peaks (Sharma, 2009) and summer maxima (Sharma and Singh, 2018). Our study records importance of Peridinium cinctum > Ceratium hirudinella; the former contributes to autumn peak and autumn maxima at the two regions, respectively; $P$. cinctum influences Dinophyta abundance $\left(\mathrm{r}_{2}=\right.$ $0.667, \mathrm{p}=0.035$ ) at the limnetic region, while $C$. hirudinella results in spring peak and autumn maxima at the two regions. ANOVA registers significant monthly density variations of the two species (Table 4).

Chrysophyta, represented by Dinobryon sociale, depicts limited quantitative importance (Table 3) with winter peaks at the two regions. This pattern differs from poor Chrysophyta abundance known from the floodplain lakes (Sharma, 2009, 2010, 2012, 2015) and reservoirs (Sharma, 1995; Sharma and Lyngdoh, 2003; Sharma and Lyngskor, 2003) of NEI. Amongst other phytoplankton groups, Cyanobacteria, Cryptophyta and Euglenophyta depict very poor abundance (Table $3)$. The present report differs from Cyanobacteria sub-dominance reported by Baba and Pandit (2014), Sharma (2015), Sharma and Pachuau (2016), Sharma and Hatimuria (2017) from the different parts of north India, while insignificance of
Cryptophyta and Euglenophyta concurs with the results of Sharma (2009), Sharma, and Pachuau (2016).

Phytoplankton record moderate species diversity (Table 3) with oscillating monthly variations at the two regions (Figure 7); ANOVA affirms its significant variations between the regions and months (Table 4). This study records $\mathrm{H}^{\prime}>2.5$ during five (March-July) and three (January, February and April) months at two stations, respectively. The relatively higher diversity at the littoral than the limnetic region is attributed both to higher richness and abundance at the former region. The notable diversity variations recorded in the present study visa-vis the earlier survey (Sharma, 1995) are attributed to distinct increase in the richness and abundance of phytoplankton during the present survey. The inverse influence of phytoplankton abundance on species diversity $\left(\mathrm{r}_{1}=-0.723, \mathrm{p}=\right.$ 0.018 ) at the littoral region is supported by concurrence of peak diversity during July (monsoon) with lowest abundance. The diversity is positively influenced by phytoplankton richness $\left(\mathrm{r}_{2}=0.760, \mathrm{p}=0.011\right)$ and Cosmarium spp. $\left(\mathrm{r}_{2}=0.757, \mathrm{p}\right.$ $=0.011)$ abundance at the limnetic region; it is inversely influenced by abundance of Staurastrum spp. $\left(\mathrm{r}_{1}=-0.738, \mathrm{p}=\right.$ $0.015), S$. arctiscon $\left(\mathrm{r}_{1}=-0.708, \mathrm{p}=0.022\right)$ and $S$. freemani $\left(r_{1}=-0.736, p=0.015\right)$ at the littoral region. An inverse influence of species diversity vs. dominance $\left(\mathrm{r}_{1}=-0.787, \mathrm{p}=\right.$ $0.007 ; r_{2}=-0.755, p=0.012$ ) is affirmed by concurrence of the lower diversity with higher dominance at both regions. Further, the diversity is positively influenced by evenness $\left(\mathrm{r}_{1}=0.986, \mathrm{p}<0.0001 ; \mathrm{r}_{2}=0.891, \mathrm{p}=0.0005\right)$ at the two regions.

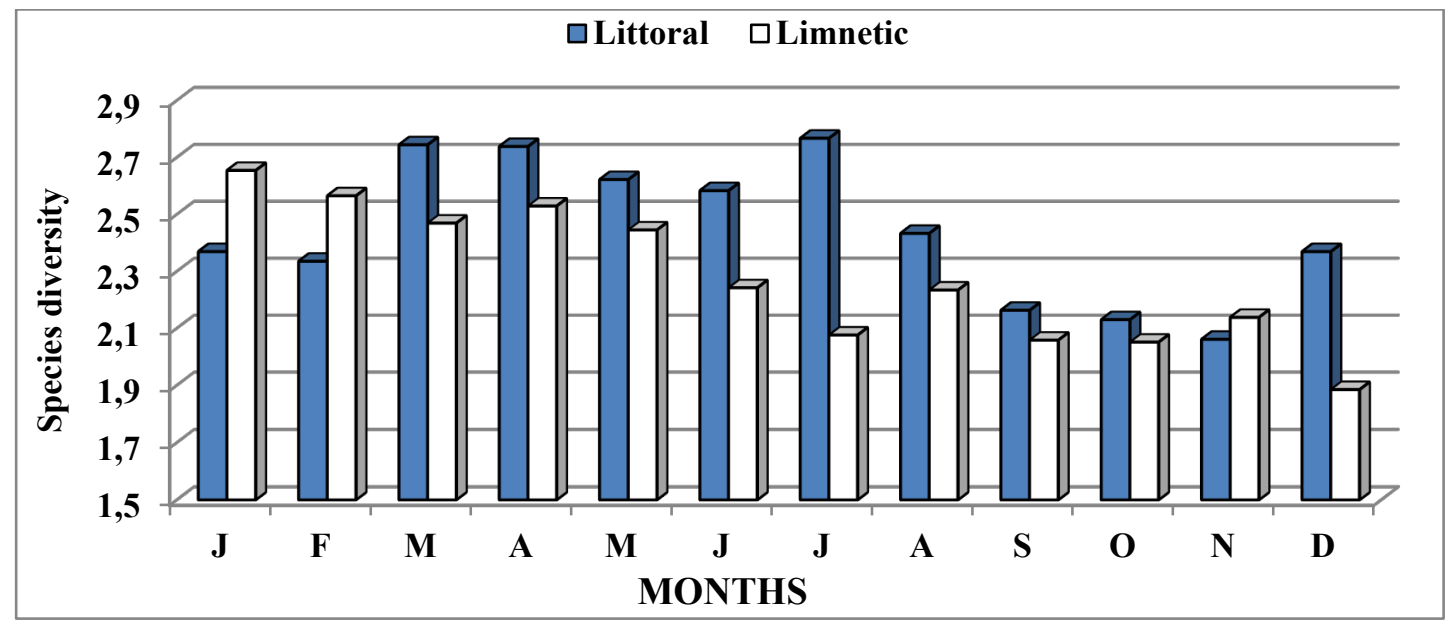

Figure 7. Monthly variations of phytoplankton species diversity 
Phytoplankton dominance depicts the spatial differences at the two regions (Table 3); peak dominance and maxima at the littoral region are noted during autumn (November) and winter (February), respectively, while it records winter peak (December) and winter maxima (January) at the limnetic region. The 'specialist' species result in higher dominance during certain months, while low dominance during certain other months is concurrent with equitable abundance of the 'generalist' species. The dominance is positively correlated with abundance of Cosmarium spp. $\left(\mathrm{r}_{1}=0.763, \mathrm{p}=0.020\right)$ and $C$. decoratum $\left(\mathrm{r}_{1}=0.784, \mathrm{p}=0.020\right)$ at the littoral region. The extant of dominance variations broadly correspond with the reports of Sharma and Pachuau (2016), Sharma and Hatimuria (2017) but differs from low dominance reported from the reservoirs of Meghalaya (Sharma and Lyngdoh, 2003; Sharma and Lyngskor, 2003) and the floodplains of NEI (Sharma, 2004, 2009, 2010, 2012, 2015). Our results depict the spatial differences of phytoplankton evenness at the two regions (Table 3); high evenness noticed during several months is attributed to equitable abundance of majority of taxa while dominance of certain species results in moderate evenness. These remarks are affirmed by an inverse correlation of evenness vs. dominance $\left(r_{1}=-0.846, p=0.002 ; r_{2}=-\right.$ $0.694, p=0.026$ ) at the two regions. Further, evenness is inversely influenced by Staurastrum spp. $\left(\mathrm{r}_{1}=-0.732, \mathrm{p}=\right.$ $0.016), S$. arctiscon $\left(\mathrm{r}_{1}=-0.726, \mathrm{p}=0.017\right)$ and $S$. freemani $\left(\mathrm{r}_{1}=-0.723, \mathrm{p}=0.018\right)$ and Cosmarium decoratum $\left(\mathrm{r}_{1}=-0.651\right.$, $\mathrm{p}=0.041)$ at the littoral region, and Peridinium cinctum $\left(\mathrm{r}_{1}=\right.$ $-0.788, p=0.007)$ at the limnetic region.

The present study registers the differential spatial influence of individual abiotic factors on phytoplankton assemblages. Inverse influence of water temperature $\left(\mathrm{r}_{1}=-0.941\right.$, $\mathrm{p}<0.0001)$, rainfall $\left(\mathrm{r}_{1}=-0.774, \mathrm{p}=0.0086\right)$ on phytoplankton richness at the littoral region is affirmed by lower richness during warmer months and rainy season and coincides with relatively high $\mathrm{pH}\left(\mathrm{r}_{1}=-0.768, \mathrm{p}=0.0095\right), \mathrm{Cl}\left(\mathrm{r}_{1}=-0.875, \mathrm{p}=\right.$ $0.0009)$ and $\mathrm{PO}_{4}\left(\mathrm{r}_{1}=-0.797, \mathrm{p}=0.0058\right)$. The richness concurs with the periods of high alkalinity $\left(\mathrm{r}_{2}=0.732, \mathrm{p}=0.0161\right)$, hardness $\left(\mathrm{r}_{2}=0.713, \mathrm{p}=0.0206\right), \mathrm{Ca}\left(\mathrm{r}_{2}=0.789, \mathrm{p}=0.0067\right)$ and DOM $\left(\mathrm{r}_{2}=0.805, \mathrm{p}=0.0050\right)$ at the limnetic region. Higher phytoplankton abundance observed during JanuaryMarch and again during October to December concurs with the relatively high transparency $\left(r_{1}=0.696, p=0.0026\right)$ and photosynthetic activity of the primary producers resulting in high DO ( $\left.\mathrm{r}_{1}=0.696, \mathrm{p}=0.0254\right)$, while lower abundance during monsoon season affirms inverse influence of rainfall $\left(\mathrm{r}_{1}=\right.$ -
$0.695, \mathrm{p}=0.0257)$ at the littoral region. The periods of high phytoplankton abundance result in increased DO $\left(\mathrm{r}_{2}=0.759\right.$, $\mathrm{p}=0.0109$ ) at the limnetic region. This conclusion also holds valid for the positive correlations of Charophyta $\left(\mathrm{r}_{1}=0.808\right.$, $\mathrm{p}=0.0047 ;\left(\mathrm{r}_{2}=0.818, \mathrm{p}=0.0038\right)$ and Staurastrum $\mathrm{spp} .\left(\mathrm{r}_{1}=\right.$ $\left.0.718, p=0.0194 ; r_{2}=0.825, p=0.0033\right)$ abundance with DO at the two regions, and with Bacillariophyta $\left(\mathrm{r}_{2}=0.856, \mathrm{p}=\right.$ $0.0047)$ at the limnetic region. High Dinophyta abundance concurs with high specific conductivity $\left(\mathrm{r}_{1}=0.803, \mathrm{p}=\right.$ 0.0052 ) at the littoral region. Bacillariophyta abundance concurs with months of high $\mathrm{Cl}$ contents $\left(\mathrm{r}_{2}=0.856, \mathrm{p}=0.0047\right)$ at the two regions; Chrysophyta abundance corresponds with high specific conductivity $\left(\mathrm{r}_{2}=0.727, \mathrm{p}=0.0172\right)$ and Dinophyta indicate low abundance during periods of high DOM $\left(\mathrm{r}_{2}=-0.679, \mathrm{p}=0.0251\right)$ at the limnetic region. Overall importance of the individual abiotic factors is concurrent with the reports of Sharma and Sharma (2021) but deviates from the importance of only a few factors (Sharma and Lyngskor, 2003; Sharma and Lyngdoh, 2003; Sharma, 2010) and much limited role of the individual factors reported vide the various works from NEI (Sharma, 1995, 2012, 2015; Sharma and Pachuau, 2016).

Referring to important species, lower alkalinity $\left(\mathrm{r}_{1}=-0.723\right.$, $\mathrm{p}=0.0181)$, hardness $\left(\mathrm{r}_{1}=-0.730, \mathrm{p}=0.0165\right), \mathrm{Ca}\left(\mathrm{r}_{1}=-0.812\right.$, $\mathrm{p}=0.0043)$ and DOM $\left(\mathrm{r}_{1}=-0.821, \mathrm{p}=0.0036\right)$ favor Staurastrum gutwinckii abundance at the littoral region, while this desmid is inversely influenced only by $\mathrm{Ca}\left(\mathrm{r}_{2}=-0.718, \mathrm{p}=\right.$ 0.0194 ) at the limnetic region. Cosmarium decoratum indicates lower densities concurrent with the periods of high temperature $\left(\mathrm{r}_{1}=-0.792, \mathrm{p}=0.0063\right)$, rainfall $\left(\mathrm{r}_{1}=-0.813, \mathrm{p}=\right.$ $0.0042), \mathrm{pH}\left(\mathrm{r}_{1}=-0.747, \mathrm{p}=0.0130\right)$ and $\mathrm{Cl}\left(\mathrm{r}_{1}=-0.819, \mathrm{p}=\right.$ $0.0038)$ at the littoral region. Navicula radiosa is inversely influenced by water temperature $\left(\mathrm{r}_{1}=-0.718, \mathrm{p}=0.0194\right)$ and $\mathrm{Cl}\left(\mathrm{r}_{1}=-0.725, \mathrm{p}=0.0177\right) ;$ Tabellaria flocculosa is positively influenced by DO $\left(\mathrm{r}_{1}=0.694, \mathrm{p}=0.0181\right)$ and NO3 $\left(\mathrm{r}_{1}=\right.$ $0.880, \mathrm{p}=0.0008$ ); and Ceratium hirudinella is positively influenced by alkalinity $\left(\mathrm{r}_{2}=0.771, \mathrm{p}=0.0090\right)$, hardness $\left(\mathrm{r}_{2}=\right.$ $0.705, \mathrm{p}=0.0228), \mathrm{Ca}\left(\mathrm{r}_{2}=0.719, \mathrm{p}=0.0191\right)$ and DOM $\left(\mathrm{r}_{2}=\right.$ $0.817, \mathrm{p}=0.0040)$ at the limnetic region. Peridinium cinctum is positively influenced by NO3 $\left(\mathrm{r}_{2}=0.684, \mathrm{p}=0.0292\right)$ and Staurastrum arctiscon is positively influenced by DO $\left(\mathrm{r}_{2}=\right.$ $0.794, p=0.0061)$ at the limnetic region. Our results thus endorse the differential spatial influence of the individual abiotic factors on notable phytoplankton species broadly concurrent with the report of Sharma and Sharma (2021). This generalization, however, marks departure from the results of 
Sharma (1995, 2009. 2010, 2012, 2015), Sharma and Lyngdoh (2003) Sharma and Pachuau (2016) and Sharma and Hatimuria (2017) yielding little insight on influence of individual abiotic factors on important species.

The CCA registers high and broadly identical cumulative influence (73.01 and 71.14\%) of 10 abiotic factors, along 1 and 2 axes, on the littoral and limnetic phytoplankton assemblages, respectively (Figures 8-9). The CCA co-ordination biplot indicates influence of alkalinity and hardness on abundance of Ceratium hirudinella and Frustulia rhomboides; rainfall on richness of phytoplankton and limited influence on Dinophyta abundance; $\mathrm{PO}_{4}$ on Tabellaria flocculosa density; specific conductivity and transparency on Staurastrum gutwinckii; dissolved oxygen on phytoplankton abundance and limited influence on Staurastrum spp., S. arctiscon and $S$. freemani; and DOM on Charophyta and Bacillariophyta, and limited influence on Cosmarium spp. and C. decoratum at the littoral region (Figure 8). The CCA biplot registers influence of alkalinity and hardness on Ceratium hirudinella; alkalinity and DOM phytoplankton and Bacillariophyta abundance; DO on Charophyta abundance and limited influence on Staurastrum spp., S. arctiscon and S. freemani at the limnetic region (Figure 9). Higher overall cumulative influence of abiotic factors reported vide this study is concurrent with the reports from Khawiva reservoir of Mizoram (Sharma and Pachuau, 2016); Bhereki and Holmari beels (Sharma and Hatimuria, 2017) of the Majuli floodplains, and Deepor beel (Sharma, 2015) of Assam.

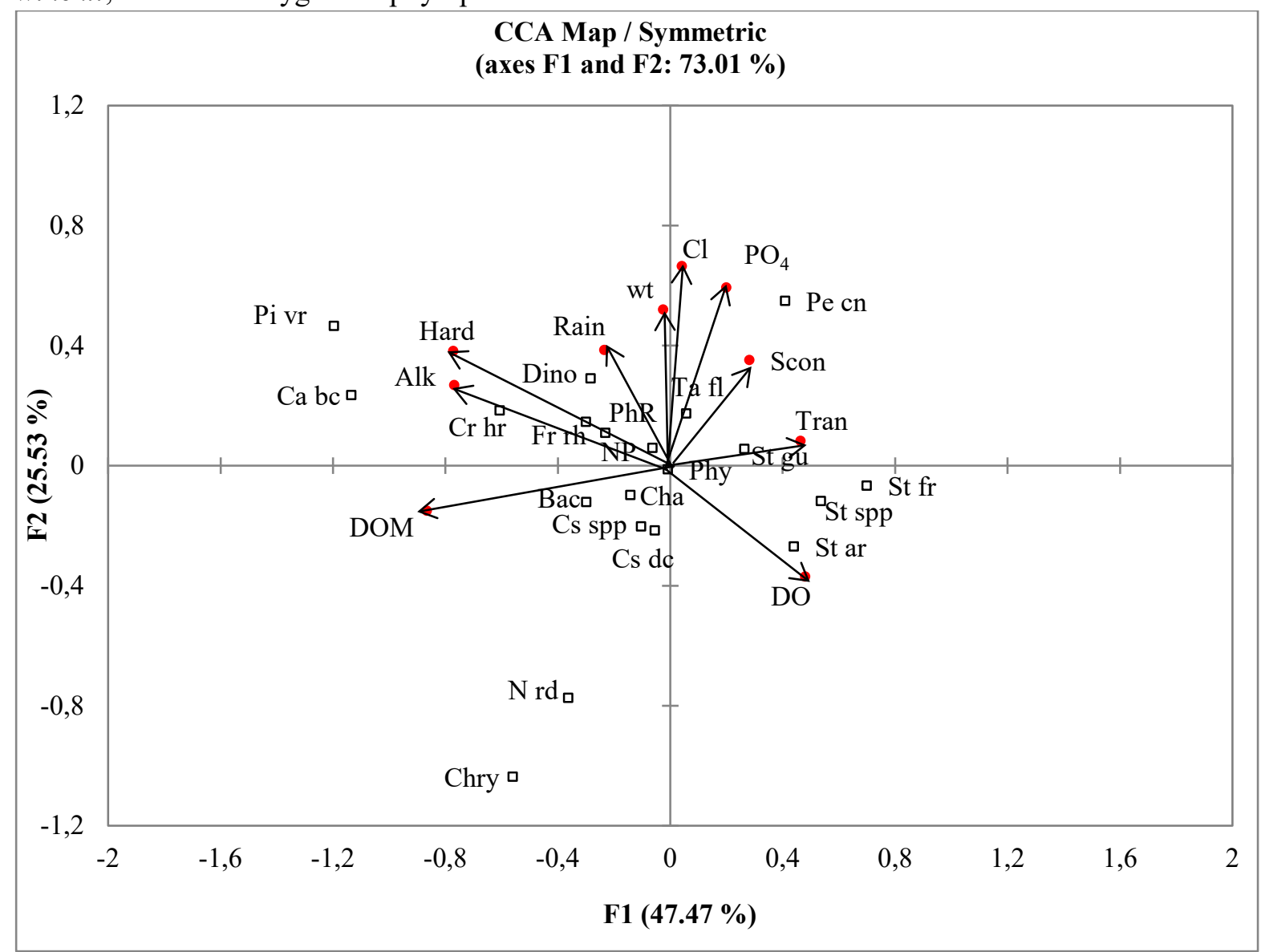

Abbreviations: Abiotic factors: Alk (alkalinity), Cl (chloride), Cond (specific conductivity), DO (dissolved oxygen), DOM (dissolved organic matter, hard (hardness), rain (rainfall), Trans (transparaency), $\mathrm{PO}_{4}$ (phosphate), wt (water temperature):. Biotic factors: Bac (Bacillariophyta abundance), Ca sp. (Caloneis bacillum), Cha (Charophyta abundance), Chry (Chrysophyta abundance), Cs spp (Cosmarium species abundance), Cr hr (Ceratium hirudinella abundance), Cs dc. (Cosmarium decoratum abundance), Dino (Dinophyta abundance), Fr rh (Frustulia rhomboides), NP (net plankton abundance), N rd (Navicula radiosa abundance), Pe cn (Peridinium cinctum abundance), Pi vr (Pinnularia viridis abundance) PhR (phytoplankton richness), Phy (phytoplankton abundance), St spp (Staurastrum species.), St ar (Staurastrum arctiscon), St fr (Staurastrum formosum abundance), St gu (Staurastrum gutwinckii abundance). Tb fl (Tabellaria flocculosa abundance)

Figure 8. CCA coordination biplot of phytoplankton assemblages and abiotic factors (Littoral region) 


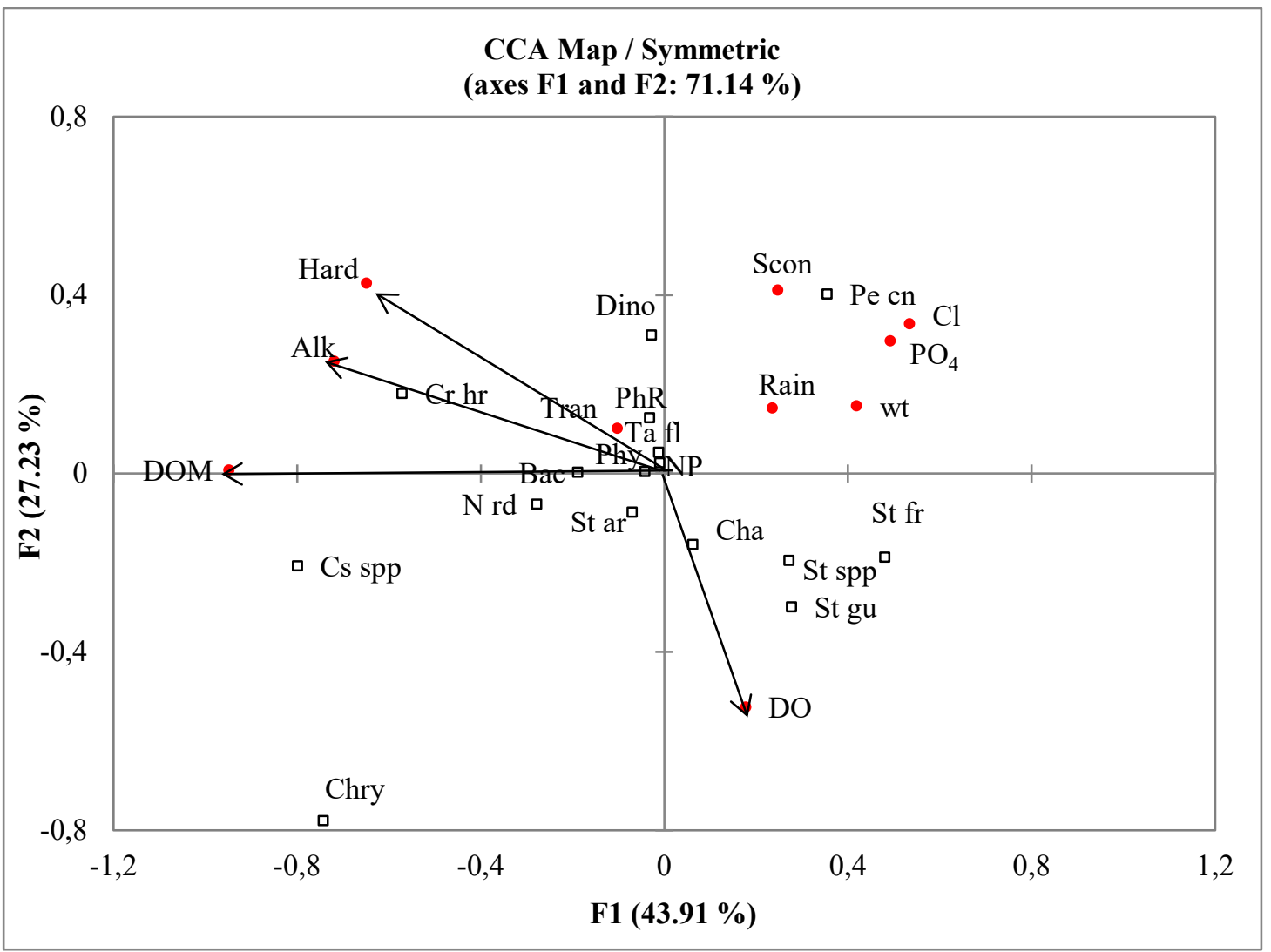

Abbreviations: Abiotic factors: Alk (alkalinity), Cl (chloride), Cond (specific conductivity), DO (dissolved oxygen), DOM (dissolved organic matter), hard (hardness), rain (rainfall), Trans (transparaency), $\mathrm{PO}_{4}$ (phosphate), wt (water temperature): Biotic factors: Bac (Bacillariophyta abundance), Cha (Charophyta abundance), Chry (Chrysophyta abundance), Cs spp (Cosmarium species abundance), Cr hr (Ceratium hirudinella abundance), Dino (Dinophyta abundance), NP (net plankton abundance), N rd (Navicula radiosa abundance), Pe cn (Peridinium cinctum abundance), PhR (phytoplankton richness), Phy (phytoplankton abundance), St spp (Staurastrum species.), St ar (Staurastrum arctiscon), St fr (Staurastrum formosum abundance), St gu (Staurastrum gutwinckii abundance). $\mathrm{Tb} \mathrm{fl}$ (Tabellaria flocculosa abundance)

Figure 9. CCA coordination biplot of phytoplankton assemblages and abiotic factors (Limnetic region)

\section{Conclusion}

The fairly diverse phytoplankton, rich Charophyta with diverse desmids, and peak constellation per sample of 30 species are notable features of very soft, acidic, highly calcium poor and one of the most de-mineralized waters of this small subtropical reservoir in particular. Phytoplankton dominance vs. net plankton abundance, the spatial differences of dominance of important groups, the reports 11 and 6 'specialist' species and Staurastrum spp. > Cosmarium spp. importance at the littoral and the limnetic regions are noteworthy. The differential spatio-temporal variations of species composition, richness, abundance, diversity, dominance, evenness and influence of the individual abiotic factors are hypothesised to habitat heterogeneity amongst the sampled regions. The CCA registers high cumulative influence of 10 abiotic factors on phytoplankton assemblages. Our results highlight distinct temporal differences of phytoplankton richness, abundance and species diversity vis-a-vis the limited survey of November 1990-October 1991. This study is an important contribution to the reservoir limnology and phytoplankton diversity of India and the subtropical reservoirs of NEI in particular. 


\section{Compliance with Ethical Standard}

Conflict of interests: The authors declare that for this article they have no actual, potential or perceived conflict of interests.

Ethics committee approval: -

Funding disclosure: A part of research work of Department of Zoology, NEHU, Shillong

Acknowledgments: The senior author thanks the Head, Department of Zoology, North-Eastern Hill University, Shillong for the laboratory facilities and to various research students for the field work help. We thank our anonymous reviewers for useful comments and suggestions.

Disclosure: -

\section{References}

Anand, N. (1998). Indian Freshwater Microalgae. Bishen Singh Mahendra Pal Singh, Dehradun, 94 p.

APHA (1992). Standard methods for the examination of water and wastewater (18th Ed.). American Public Health Association, Washington D.C. 1198 p.

Baba, A.I., Pandit, A.K. (2014). Composition, diversity and population dynamics of phytoplankton at Saderkot in Wular Lake, Kashmir. Journal of Ecosystem \& Ecography, 4(1), 142.

https://doi.org/10.4172/2157-7625.1000142

Bharati, H., Deshmukhe, G., Das, S.K., Kandpal, B.K., Sahoo, L., Bhusan, S., Singh, Y.J. (2020). Phytoplankton communities in Rudrasagar Lake, Tripura (North-East India) - A Ramsar Site. International Journal of Bio-resource and Stress Management, 11(1), 1-7.

https://doi.org/10.23910/IJBSM/2020.11.1.2030

Devi, M.B., Gupta, S., Das, T. (2016). Phytoplankton community of Lake Baskandi anua, Cachar District, Assam, North East India - An ecological study. Knowledge and Management of Aquatic Ecosystems, 417, 2.

https://doi.org/10.1051/kmae/2015034

Fritter, R., Manuel R. (1986). Field guide to the Freshwater life of Britain and North-West Europe. William Collins Sons \& Co. Ltd, London, 382 p.
Ganai, A.H., Parveen, S. (2014). Effect of physico-chemical conditions on the structure and composition of the phytoplankton community in Wular Lake at Lankrishipora, Kashmir. International Journal of Biodiversity and Conservation, 6(1), 71-84.

https://doi.org/10.5897/IJBC2013.0597

Goswami, M., Das, T., Kumar, S., Mishra, A. (2018). Impact of physico-chemical parameters on primary productivity of Lake Nainital. Journal of Entomology and Zoology Studies, 6(4), 647-652.

Gupta, S., Singh, D., Rawat, M.S., Ahmed, R. (2018). Phytoplankton community in relation to physicochemical characteristics of Renuka Lake and Parshuram Tal (H.P.), India. International Journal of Scientific Research and Reviews, 7(3), 769-780.

Hickel, B. (1973). Limnological investigation in lakes of the Pokhra valley. Internationale Revue der gesamten Hydrobiologie, 58(5), 659-672.

https://doi.org/10.1002/iroh.19730580506

Islam, A.K.M.N., Haroon, A.K.Y. (1980). Desmids of Bangladesh. Internationale Revue gesamten Hydrobiologie, 65(4), 551-604.

https://doi.org/10.1002/iroh.19800650416

Jindal, R., Thakur, R.K. (2014). Hydrobiology and productivity of Kuntbhyog Lake, (District Mandi, Himachal Pradesh), India. International Journal of Environmental Engineering, 6 (4), 449-459.

https://doi.org/10.1504/IJEE.2014.067004

Jindal, R., Thakur, R.K., Singh, U.B., Ahluwalia, A.S. (2013). Plankton diversity and water quality assessment of three freshwater lakes of Mandi (Himachal Pradesh, India) with special reference to planktonic indicators. Environmental Monitoring \& Assessment, 185 (10), 8355-8373.

https://doi.org/10.1007/s10661-013-3178-3

Jindal, R., Thakur, R.K., Singh, U.B., Ahluwalia, A.S. (2014a). Phytoplankton dynamics and species diversity in a shallow eutrophic, natural mid-altitude lake in Himachal Pradesh (India): role of physicochemical factors. Chemistry and Ecology, 30(4), 328-338. 
https://doi.org/10.1080/02757540.2013.871267

Jindal, R., Thakur, R.K., Singh, U.B., Ahluwalia, A.S. (2014b). Phytoplankton dynamics and water quality of Prashar Lake, Himachal Pradesh, India. Sustainability of Water Quality and Ecology, 3-4, 101-113.

https://doi.org/10.1016/j.swaqe.2014.12.003

John, D.M., Whitton, B.A., Brook, A.J. (2002). The Freshwater Algal Flora of the British Isles: An Identification Guide to Freshwater and Terrestrial Algae. Cambridge University Press: Cambridge, UK.

Ludwig, J.A., Reynolds J.F. (1988). Statistical ecology: a primer on methods and computing. John Wiley \& Sons, New York, $337 \mathrm{p}$.

MacArthur, R.H. (1965). Patterns of spices diversity. Biological Reviews, 40, 510-533.

https://doi.org/10.1111/j.1469-185X.1965.tb00815.x

Negi R.K., Rajput, V. (2015). Assessment of phytoplankton diversity in relation to abiotic factors of Nainital Lake of $\mathrm{Ku}-$ maon Himalayas of Uttarakhand State, India. Asian Journal of Scientific Research, 8(2), 157-164.

https://doi.org/10.3923/ajsr.2015.157.164

Payne, A.R. (1986). The ecology of Tropical Lakes and Rivers. John Wiley \& Sons, New York.

Prescott, G.W. (1982). Algae of the Western Great Lakes area, Ottokoeltz Science Publishers, W. Germany, 977 p.

Sharma B.K. (1995). Limnological studies in a small reservoir in Meghalaya (N.E. India). In K.H. Timotius \& F. Goltenboth (Eds.). Tropical Limnology, II, 1-11. Satya Wacana University Press, Salatiga, Indonesia.

Sharma B.K. (2004). Phytoplankton communities of a floodplain lake of the Brahmaputra river basin, Upper Assam. Journal of Inland Fisheries Association, 31, 27-35.

Sharma B.K. (2009). Phytoplankton communities of Loktak lake (a Ramsar site), Manipur (N. E. India): composition, abundance and ecology. Journal of Threatened Taxa, 1(8), 401-410.
https://doi.org/10.11609/JoTT.o2193.401-10

Sharma, B.K. (2010). Phytoplankton diversity of two floodplain lakes (pats) of Manipur (N. E. India). Journal of Threatened Taxa, 2(11), 1273-1281.

https://doi.org/10.11609/JoTT.o2427.1273-81

Sharma, B.K. (2012). Phytoplankton diversity of a floodplain lake of the Brahmaputra River basin, Assam, north-east India. Indian Journal of Fisheries, 59(4), 131-139.

Sharma, B.K. (2015). Phytoplankton diversity of Deepor Beel- a Ramsar site in the floodplain of the Brahmaputra River Basin, Assam, north-east India. Indian Journal of Fisheries, 62(1), 33-40.

Sharma, B.K., Bhattarai, S, (2005). Hydro-biological analysis of a peat bog with emphasis on its planktonic diversity and population dynamics in Bumdeling Wildlife Sanctuary: eastern Bhutan. Limnology, 6, 183-187.

https://doi.org/10.1007/s10201-005-0157-6

Sharma, B.K., Hatimuria, M.K. (2017). Phytoplankton diversity of floodplain lakes of Majuli River Island, Brahmaputra river basin of Assam, northeast India. International Journal of Aquatic Biology, 5(5), 295-309.

Sharma, B.K., Lyngdoh, R.M. (2003). Abundance and ecology of net and phytoplankton of a subtropical reservoir of Meghalaya (N. E. India). Ecology, Environment \& Conservation, 9(4), 497-503.

Sharma, B.K., Lyngskor, C. (2003). Plankton communities of a subtropical reservoir of Meghalaya (N. E. India). Indian Journal of Animal Sciences, 73(2), 88-95.

Sharma, B.K., Pachuau, L. (2016). Diversity of Phytoplankton of a sub-tropical reservoir of Mizoram, northeast India. International Journal of Aquatic Biology, 4(6), 360-369.

Sharma, B.K., Sharma, S. (2021). Phytoplankton diversity of a subtropical reservoir of Meghalaya state of northeast India. Aquatic Sciences \& Engineering, 36(2), 51-65.

https://doi.org/10.26650/ASE2020740218 
Sharma, R.C., Singh, S. (2018). Water quality and phytoplankton diversity of high altitude wetland, Dodi Tal of Garhwal Himalaya, India. Biodiversity International Journal, 2(6), 484-493.

https://doi.org/10.15406/bij.2018.02.00103

Sharma, R.C., Tiwari, V. (2018). Phytoplankton diversity in relation to physico-chemical environmental variables of Nachiketa Tal, Garhwal Himalaya. Biodiversity International Journal, 2(2), 128-136.

https://doi.org/10.15406/bij.2018.02.00052

Thakur, R.K., Jindal, R., Singh, U.B., Ahluwalia, A.S. (2013). Plankton diversity and water quality assessment of three freshwater lakes of Mandi (Himachal Pradesh, India) with special reference to planktonic indicators. Environment Monitoring \& Assessment, 185 (10), 8355-8373.

https://doi.org/10.1007/s10661-013-3178-3
Wanganeo, A., Wanganeo, R. (1991). Algal population in valley lakes of Kashmir Himalayas. Archiv fur Hydrobiologie, 121, 219-223.

Woelkerling, W., Gough S.B. (1976). Wisconsin Desmids. III. Desmid community composition and distribution in relation to lake type and water chemistry. Hydrobiologia, 51, 3-32.

https://doi.org/10.1007/BF00007982

Zutshi, D.P., Wanganeo, A. (1984). The phytoplankton and primary productivity of a high altitude subtropical lake. Internationale Vereinigung für Theoretische und Angewandte Limnologie Verhandlungen, 222, 1168-1172.

https://doi.org/10.1080/03680770.1983.11897457 